\title{
Simulation of Oncideres saga (Dalman) girdling over Acacia mangium Willd. development
}

\author{
Simulação do roletamento de Oncideres saga (Dalman) sobre o \\ desenvolvimento de Acacia mangium Willd.
}

\author{
Gláucia Cordeiro', Pedro Guilherme Lemes ${ }^{2}$, Carolina Rocha da Silva ${ }^{1}$, \\ Hélio Garcia Leite ${ }^{3}$ and Norivaldo dos Anjos ${ }^{1}$
}

\begin{abstract}
The objective was to evaluate the effect of cutting the central leader, in a similar way to that performed by Oncideres saga (Dalman), on the diameter and height growth of Acacia mangium Willd. trees. An experiment was carried out in May 2007 in Coimbra, Minas Gerais, Brazil, with a randomized complete block design, split by the time according to the age of the trees ( 40 to 46 months). A total of 54 trees were monthly evaluated in three blocks, where three treatments were applied, with six trees in each experimental plot. The applied treatments consisted of "uninjured" ( $\mathrm{T} 1=$ control), "complete defoliation of the central leader" (T2) and "cutting the central leader" (T3). The diameter at breast height (DBH) and the total height (H) of each tree in the experiment were evaluated. The results were submitted to analysis of variance, test of significance, regression analysis and identity test models. The diameter and height had an increasing linear growth rate. The cutting of the central leader, similar to that made by $O$. saga, affected growth in height. The height growth of the trees that had the central leader cut had an equivalent effect to those that were defoliated.
\end{abstract}

Keywords: Forest entomology; Twig girdler; Injury; Artificial defoliation.

\section{Resumo}

O objetivo desse trabalho foi avaliar o efeito do corte do ponteiro principal de Acacia mangium Willd., semelhante ao realizado por Oncideres saga (Dalman), sobre o crescimento em diâmetro e altura. Um experimento foi instalado, em maio de 2007, com delineamento em blocos ao acaso, parcelas subdivididas no tempo em função das idades das árvores (40 a 46 meses), em Coimbra-MG. Avaliou-se mensalmente 54 árvores, dispostas em três blocos onde foram aplicados três tratamentos, com seis árvores em cada parcela experimental. Os tratamentos aplicados consistiram em "Sem injúria" (T1=Testemunha), "Desfolhamento do ponteiro principal" (T2) e "Corte do ponteiro principal" (T3). Foi avaliado o diâmetro com casca a $1,30 \mathrm{~m}$ de altura (DAP) e a altura total $(\mathrm{H})$ de cada árvore no experimento. Os resultados obtidos foram submetidos à análise de variância, teste de significância, analise de regressão e teste de identidade de modelos. Como resultado, constatou-se que o diâmetro e a altura apresentação taxa de crescimento linear crescente. $\mathrm{O}$ corte do ponteiro principal, à semelhança do que faz $O$. saga, afetou o crescimento em altura. $\mathrm{O}$ crescimento em altura das árvores que tiveram o ponteiro principal cortado apresentou efeito equivalente àquelas que foram desfolhadas.

Palavras-chave: Entomologia Florestal, Serrador; Injúria; Desfolha artificial

\section{INTRODUCTION}

In 2017 Brazil had more than seven million hectares planted of Eucalyptus spp., Pinus spp. and some plantations such as Acacia spp., Araucaria angustifolia, Hevea brasiliensis, Populus spp. and Tectona grandis. Acacia spp. plantations corresponded to approx. 160 thousand ha, with most of them in the States of Rio Grande do Sul, with Acacia mearnsii De Willd. and Roraima, with Acacia mangium Willd. (AGEFLOR, 2017; ARCO-VERDE, 2002; IBÁ, 2018).

\footnotetext{
1. Entomology Department, Universidade Federal de Viçosa - UFV. Viçosa, MG, Brazil.

2. Institute of Agricultural Sciences, Universidade Federal de Minas Gerais - UFMG. Montes Claros, MG, Brazil.

3. Forestry Department, Universidade Federal de Viçosa - UFV. Viçosa, MG, Brazil.

Corresponding author: glaucordeiro@gmail.com
}

Sci. For., Piracicaba, v. 47, n. 124, p. 604-612, dez. 2019

DOI: doi.org/10.18671/scifor.v47n124.02 
Defoliation caused by insects may decrease the leaf area and, consequently, reduce wood production, as it decreases the photosynthesis rate (CEULEMANS; SAUGIER, 1991). The effects of defoliation have been studied using trees damaged by insects or through artificial defoliation (ABBOTT et al., 1993; CANTARELLI et al., 2008; FERNANDES, 2004; FREITAS; BERTI FILHO, 1994a,b; FREITAS; MACHADO, 1998; MAFIA et al., 2014; MATRANGOLO et al., 2014; MENDES, 1999; 2004; DE NADAI et al., 2012; OLIVEIRA et al., 2014; REIS FILHO et al., 2011). The tree, in order to replace its lost leaf area, is disturbed in its use of photo-assimilates, which may affect its development and production (DICKSON, 1991).

Trees defoliated by beetles may have growth reduction, poor wood quality and even die (CORDEIRO et al., 2006; FERNANDES, 2004; MENDES, 1999; 2004; DE NADAI et al. 2012; PEDROZO, 1980). The effects of defoliation caused by beetles known as "twig girdlers" were until now, poorly evaluated (CORDEIRO et al., 2006; LEMES et al., 2013; PEDROZO, 1980).

Most of these beetles belong to the genus Oncideres (Cerambycidae: Lamiinae) (CARAGLIO et al., 2001; DI IORIO, 1996). They are known as twig girdlers because they girdle branches and central leaders of trees, which the females use as a oviposition site. The Oncideres girdling behavior may facilitate the action of plant pathogens, alter tree canopy architecture, reduce seed production, interfere with reproduction capacity and increase mortality rate of girdled trees. The greatest damage occurs when the central leader is girdled, causing bifurcations and depreciating the wood's commercial value (CARAGLIO et al., 2001; COULSON, 1979; COUTINHO et al., 1998; ROMERO et al., 2005).

Adult twig girdlers usually emerge in October in most parts of Brazil (GALILEO; MARTINS, 2006), and can live from three to four months (COUTINHO et al., 1998; LEMES et al., 2013). In the State of Minas Gerais, Oncideres saga (DALMAN, 1823) emerges between November and April and has been reported to damage A. mangium trees (CORDEIRO, 2008; LEMES et al., 2015).

The objective of this work was to test the hypothesis that $O$. saga girdling on the central leader has the same consequence as leaf loss of the central leader in the development of A. mangium, under commercial planting conditions. This hypothesis will be tested by simulating both injuries.

\section{MATERIAL AND METHODS}

Some A. mangium trees were cut in a similar way to $O$. saga girdling using a bow saw and others were manually defoliated. Both were compared to undamaged trees (control), under the same growing conditions, to test the hypothesis that branch girdling is as harmful to the trees as defoliation.

The experiment was performed in the municipality of Coimbra, Minas Gerais state, Brazil $\left(20^{\circ} 51^{\prime} 24^{\prime \prime} \mathrm{W}\right.$ and $42^{\circ} 48^{\prime} 10^{\prime \prime} \mathrm{S}$, altitude $720 \mathrm{~m}$, average annual temperature of $19^{\circ} \mathrm{C}$ and average annual rainfall ranging between 1300 to $1400 \mathrm{~mm}$ ), in May of 2007, in a plantation with approx. 3,000 A. mangium trees, 40 months old, spacing of $3 \times 2 \mathrm{~m}$, planted on a steep slope. The wood produced was for logs and fence posts. Piptadenia gonoacantha (Mart.) J. F. Macbr. and Anadenanthera macrocarpa (Benth.) Brenan trees were planted at the upper part of the slope and there were banana and eucalyptus plantations and pastures in the surroundings.

The experimental design was a randomized block design, with the plots measured at seven different ages (from 40 to 46 months); a period without occurrence of $O$. saga adults. In each of the three replicates (three blocks defined based on site physiography), 18 trees were randomly assigned. These trees were, once again, randomly divided into three groups of six trees (PEDROZO, 1980). A treatment $(\mathrm{T} 1=$ uninjured $($ control $), \mathrm{T} 2=$ complete defoliation of central leader or T3 $=$ "girdling" of the central leader) was applied in each of the three sets of six trees.

The position of the cut was defined based on the mean diameter of branches and stems girdled by $O$. saga $(3.8 \mathrm{~cm})$ and by its preference of girdling position (central leader), based in field measurements and literature review (CORDEIRO et al., 2006; VIDAURRE et al., 2001; WENDT et al., 1998). The artificial defoliation was performed from the same diameter $(3.8 \mathrm{~cm})$ towards the apex of the tree, manually removing all leaves.

The circumference at breast height $(1.3 \mathrm{~m})$ and the total height $(\mathrm{H})$ were measured in all evaluated trees, immediately after the treatments applications (40 months old) and them monthly, until the age of 46 months. The circumference was measured with a millimeter tape and the total height with a rod, with accuracy of $50 \mathrm{~cm}$, due to the slope conditions and the density of the planting. 
The mean diameter $(\mathrm{q})$ and mean total height per tree $(\mathrm{H})$ were determined for each treatment and repetition (blocks 1, 2 and 3 ) at each age. Immediately after the treatments, the variables $\mathrm{q}$ and $\mathrm{H}$ were submitted to the t test $(\alpha=0.05)$ to compare each variable among the treatments.

The hypotheses of normality of the errors (Lilieffors test at $5 \%$ of significance) and the homoscedasticity hypothesis (Hartley test at 5\% of significance) were evaluated before variances were analyzed. When these assumptions were met, the variables $\mathrm{q}$ and $\mathrm{H}$ were submitted to analysis of variance, significance test, regression analysis and model identity test, using the software Statistic 10 (STATSOFT, INC, 2012). The statistical model of the experiment was $Y_{i j}=m+b_{j}+t_{i}+e(a)+I_{l}+t_{i} I_{l}+e(b)$.

Irrespective of the significance of the interaction between main treatment and secondary treatment ( subplot = age), the necessary splits were made. The treatments were discriminated by the Tukey test, at a level of $5 \%$ of significance, for each age, when necessary. The variables $\mathrm{q}$ and $\mathrm{H}$ were correlated with age by means of regression in each treatment. Simple linear models, the quadratic model and the square root model were tested. The best model was defined for each variable based on the adjusted coefficient of determination, and by the analysis of percent residuals. A model identity test was applied when the same model was defined for two or three treatments (CUNIA, 1973).

\section{RESULTS AND DISCUSSION}

The interaction between treatment and age for the mean diameter was not significant, that is, there was no difference between undamaged A. mangium trees to those damaged (Table 1). Oliveira (2007) and Pedrozo (1980) also found no difference for the mean diameter of damaged and undamaged trees of Mimosa scabrella Benth. (Fabaceae) and A. mearnsii by Oncideres impluviata (GERMAR, 1824). This occurred because the diameters were measured soon after the treatments were applied, and the development of damaged trees was not evaluated over time (PEDROZO, 1980). In the present study, the variables were evaluated when the treatments were applied and the six months thereafter. Although the diameter growth was not different among treatments, the girdling of central leaders may reduce wood use, since the trunks become deformed, compromising the logs size, the harvest and wood processing (OLIVEIRA, 2007). Thus, future research should evaluate the effects of girdling on the tree shape and wood quality.

Although interaction between treatment and age was not significant for mean diameter, this interaction was spread to study the effect of each treatment at each age and the effect of age per treatment (Table 1).

The simple and quadratic linear models were adjusted and the simple linear model $Y=\beta_{0}+\beta_{1} X+\varepsilon$ was selected. The estimated equations are shown in figure 1 . The linear growth rates in mean diameter, in the evaluated time interval, were $0.16 ; 0.13$ and $0.15 \mathrm{~cm}$, for treatments 1,2 and 3, respectively.

Table 1: Analysis of variance of the mean diameter $(q)$ and height $(\mathrm{H})$ of Acacia mangium Willd. trees.

Tabela 1: Análise de variância do diâmetro médio $(\mathrm{q})$ e da altura $(\mathrm{H})$ das árvores de Acacia mangium Willd..

\begin{tabular}{|c|c|c|}
\hline \multirow{2}{*}{ Sources of variation } & mean diameter $(q)$ & height $(\mathrm{H})$ \\
\hline & \multicolumn{2}{|c|}{ significance } \\
\hline Block & ns & * \\
\hline Treat. & ns & * \\
\hline Error (a) & - & \\
\hline Age & * & * \\
\hline Treat. $x$ age & ns & ns \\
\hline Treat./40 months & ns & ns \\
\hline Treat./41 months & ns & * \\
\hline Treat./42 months & ns & * \\
\hline Treat./43 months & ns & * \\
\hline Treat./44 months & ns & * \\
\hline Treat./45 months & ns & * \\
\hline Treat./46 months & ns & * \\
\hline Age/Treat. 1 & $*$ & * \\
\hline Age/Treat. 2 & * & * \\
\hline Age/Treat. 3 & * & * \\
\hline
\end{tabular}

Treat: Treatment; *: $\mathrm{P}<0,05 ; \mathrm{ns:} \mathrm{P}>0,05$. 
Trees that had the central leader defoliated (T2) grew less in diameter. When comparing treatments one-to-one, there was no statistical identity between the mean diameter equations, and three equations were defined (Figure 1). Thus, there was no similarity, for the mean diameter, between the defoliated and "girdled" trees.

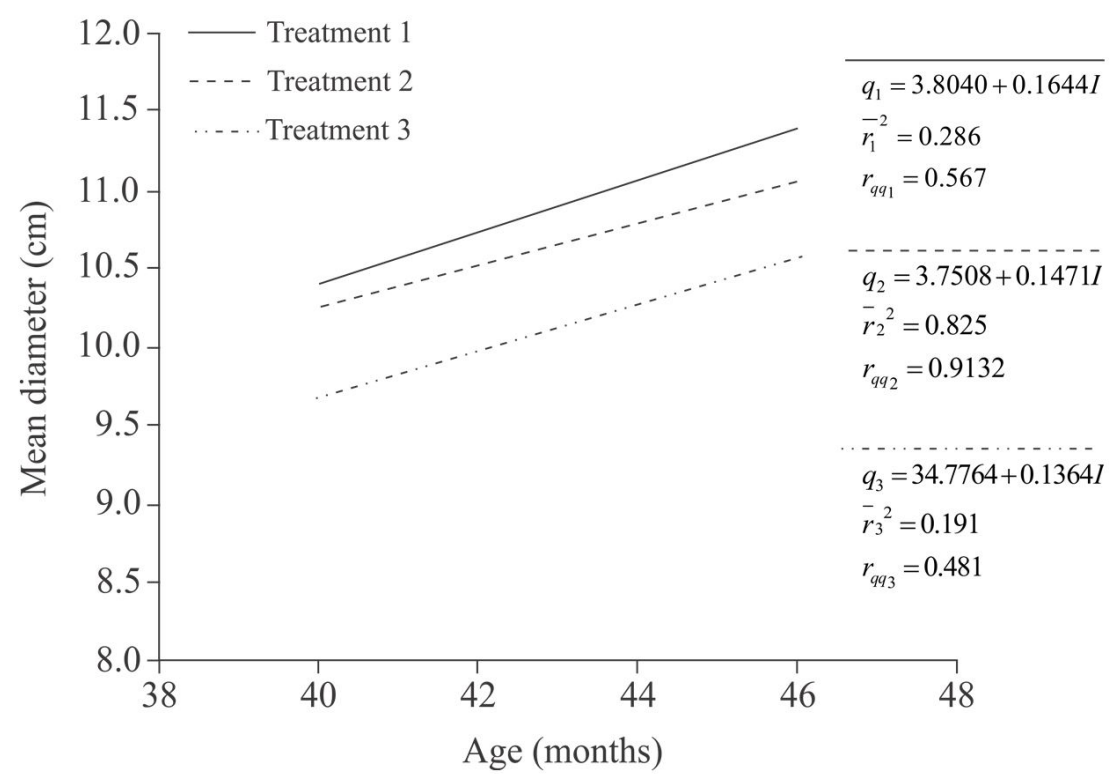

Figure 1: Diameter growth $(\mathrm{q})(\mathrm{cm})$ of Acacia mangium trees submitted to treatments (Treatment $1=$ uninjured; Treatment 2 = Complete defoliation of the central leader; Treatment 3 = "girdling" of the central leader). $\left(r^{2}\right.$ : Coefficient of determination; $r_{q q}$ : Coefficient of correlation).

Figura 1: Crescimento em diâmetro de árvores $(\mathrm{q})(\mathrm{cm})$ de Acacia mangium submetidas aos tratamentos, Tratamento 1 = Sem injúria; Tratamento $2=$ Desfolhamento do ponteiro principal; Tratamento $3=$ Corte do ponteiro principal. ( $r^{2}$ : Coeficiente de determinação; $r_{q q}$ : Coeficiente de correlação).

Diameter growth was different between uninjured trees and those defoliated by beetles (ABBOTT et al., 1993; FERNANDES, 2004; FREITAS; BIERTI FILHO, 1994a; MENDES, 2004; 1999). Eucalyptus grandis W.Hill ex Maiden (Myrtaceae) trees have their initial growth reduced by Costalimaita ferruginea (FRABRICIUS, 1801) (Coleoptera: Chrysomelidae) defoliation. The losses in the mean diameter tend to rise between the first and the second year after the damage, in trees with greater intensity of defoliation (MENDES, 1999). These authors worked with a one year time interval, and it can be inferred that the trees evaluated in our research had not yet expressed the full consequences of the injuries. In addition, the trees were only injured once and it is known that twig girdlers may girdle several branches of the same tree (CORDEIRO et al., 2010; LEMES et al., 2013; 2012; SOUZA et al., 2012). Thus, it is expected that the effects of damage would increase over time as demonstrated by Mendes (2004).

The analysis of variance for height demonstrates that there was a difference for the blocks in the main and secondary treatment (Table 1).

When spreading the treatment $\mathrm{X}$ age interaction and using Tukey's test, to check the effect of height of each main treatment in each secondary treatment, it was found that at ages 43 and 44 months, the height of the trees with the central leader defoliated (T2) were equivalent to those with a "girdled" central leader (T3) and that the height of the undamaged trees (T1) were different from those with "girdled" central leader (T3) (Table 2).

Table 2: Mean height $(\mathrm{H})(\mathrm{m})$ of Acacia mangium Willd. trees (Treatment $1=$ uninjured; Treatment $2=$ Complete defoliation of the central leader; Treatment 3 = "girdling" of the central leader).

\begin{tabular}{ccccccccc}
\hline \multirow{2}{*}{ Treatment } & \multicolumn{7}{c}{ Age (months) } \\
\cline { 2 - 8 } & $\mathbf{4 0}$ & $\mathbf{4 1}$ & $\mathbf{4 2}$ & $\mathbf{4 3}$ & $\mathbf{4 4}$ & $\mathbf{4 5}$ & $\mathbf{4 6}$ \\
\hline 1 & $7,31 \mathrm{a}$ & $7,58 \mathrm{a}$ & $7,81 \mathrm{a}$ & $7,98 \mathrm{~b}$ & $8,16 \mathrm{~b}$ & $8,34 \mathrm{a}$ & $8,44 \mathrm{a}$ \\
2 & $6,99 \mathrm{a}$ & $7,25 \mathrm{a}$ & $7,37 \mathrm{a}$ & $7,49 \mathrm{ab}$ & $7,62 \mathrm{ab}$ & $7,81 \mathrm{a}$ & $7,99 \mathrm{a}$ \\
3 & $6,84 \mathrm{a}$ & $6,98 \mathrm{a}$ & $7,13 \mathrm{a}$ & $7,25 \mathrm{a}$ & $7,34 \mathrm{a}$ & $7,46 \mathrm{a}$ & $7,68 \mathrm{a}$ \\
\hline
\end{tabular}

Means followed by the same lower case letter in a column do not differ by the Tukey test $(\mathrm{P}>0.05)$. 
The regression of $\mathrm{H}=\mathrm{f}($ age $)$ was adjusted, obtaining the linear model $H=\beta_{0}+\beta_{l} I+\varepsilon$ with the best fit to express the height growth of the trees submitted to the treatments (Figure 2). The linear height growth rates, in the time interval of 40 to 46 months, were of $18.5,17.5$ and $16.8 \mathrm{~cm}$, for treatment 1,2 and 3 , respectively. Uninjured trees grew more in height than those that were damaged. The uninjured trees (T1) grew $1.13 \pm 0.56 \mathrm{~m}$ in height, while those with defoliated (T2) and "girdled" (T3) central leader grew $1.00 \pm 0.49 \mathrm{~m}$ and $0.84 \pm 0.42 \mathrm{~m}$, respectively. This corresponds to a difference of $11.5 \%$ and $25.7 \%$ in the height growth of the defoliated and girdled trees, respectively, in relation to uninjured trees.

A

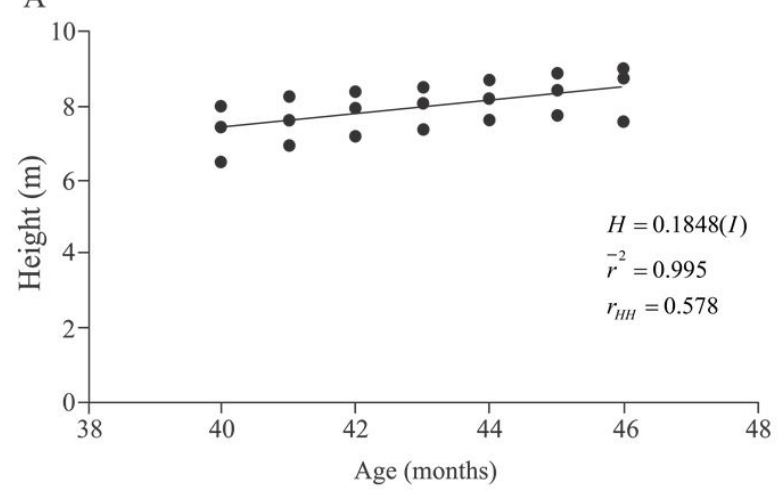

$\mathrm{B}$

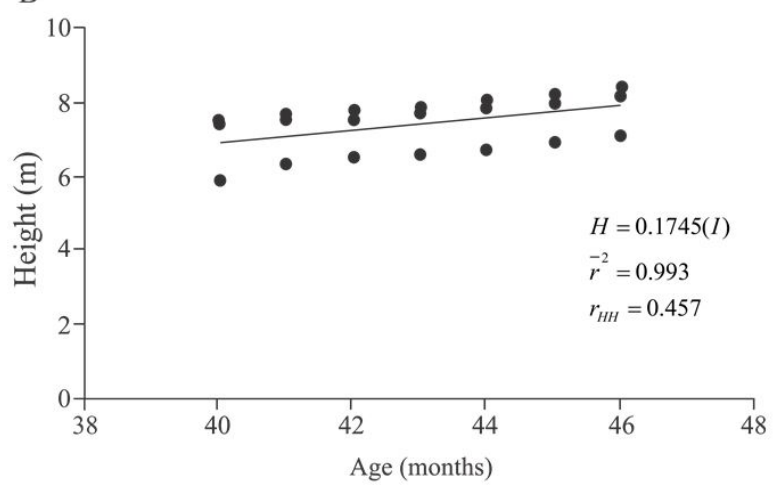

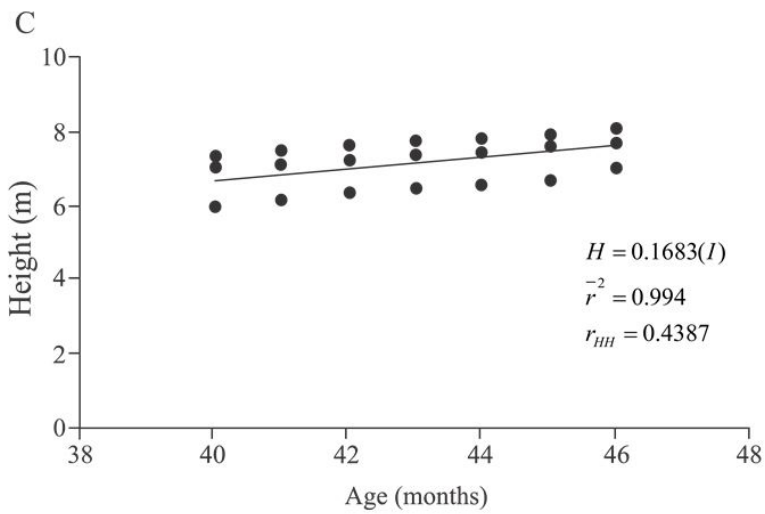

Figure 2: Mean height growth trend $(\mathrm{H})$ of Acacia mangium trees submitted to treatments: $(\mathrm{A})$ Treatment $1=$ uninjured; (B) Treatment $2=$ Complete defoliation of the central leader; (C) Treatment 3= "girdling" of the central leader. ( $r^{2}$ : Coefficient of determination; $r_{\mathrm{HH}}$ : Coefficient of correlation).

Figura 2: Tendência média do crescimento em altura $(H)$ de árvores de Acacia mangium submetidas aos tratamentos: (A) Tratamento 1= Sem injúria; (B) Tratamento 2= Desfolhamento do ponteiro principal; (C) Tratamento $3=$ Corte do ponteiro principal. ( $r^{2}$ : Coeficiente de determinação; $r_{\mathrm{HH}}$ : Coeficiente de correlação).

Defoliated trees lose competitive capacity, and do not reach the same growth rates of uninjured trees, affecting their ability to compete for water and nutrients (SCHOWALTER et al., 1986). So, effects of higher damage intensities may become even more harmful to the trees over time (OHMART et al., 1984). Trees of E. grandis defoliated by C. ferruginea were not able to recover the losses in height growth, even one year after the defoliation. Regardless of damage intensity, the growth difference between trees with less intensity to those with higher damage intensity increased over time (MENDES, 1999). Rubber trees (Hevea brasiliensis) (Euphorbiaceae) have their initial height growth proportionally reduced by the level of simulated defoliation, either when it is partial ( $25 \%$ of the crown) or total (100\% of the crown) (SILVA, 2001).

The equations (Figure 2) were compared using a model identity test. When comparing the treatments one-to-one, a statistical identity was verified between the total height of the trees with the central leader defoliated (T2) and those with the "girdled" central leader (T3). T2 and T3 trees presented the same linear growth rate in height (Figure 3). Based on these equations, as these trees develop, their height will be smaller than those of T1. 


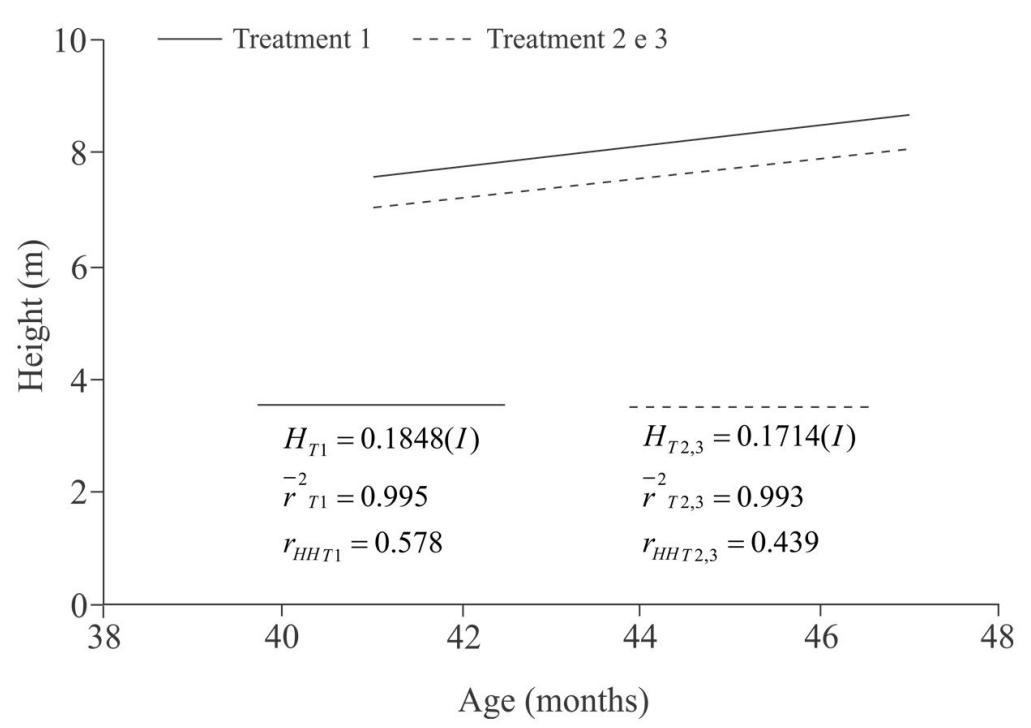

Figure 3: Height growth $(\mathrm{H})$ of Acacia mangium trees after being submitted to defoliation and girdling of the central leader $\left(\mathrm{H}_{\mathrm{T} 2,3}\right)$ and uninjured $\left(\mathrm{H}_{\mathrm{T} 1}\right)$. Treatment $1=$ uninjured; Treatment 2 = Complete defoliation of the central leader; Treatment 3 = "girdling" of the central leader $\left(r^{2}\right.$ : Coefficient of determination; $r_{\mathrm{HH}}$ : Coefficient of correlation).

Figura 3: Crescimento em altura $(\mathrm{H})$ de árvores de Acacia mangium após serem submetidas ao desfolhamento e ao corte do ponteiro principal $\left(\mathrm{H}_{\mathrm{T} 2,3}\right)$ e sem injúria $\left(\mathrm{H}_{\mathrm{T} 1}\right)$. Tratamento 1: Sem injúria; Tratamento 2: Desfolhamento do ponteiro principal; Tratamento 3: Corte do ponteiro principal. ( $r^{2}$ : Coeficiente de determinação; $\mathrm{r}_{\mathrm{HH}}$ : Coeficiente de correlação)

Defoliating beetles cause partial or total destruction of the leaves through feeding or other behaviors, reducing the photosynthetic area (WYLIE; SPEIGHT, 2012; CORASSA; SOUZA, 2014). It is known that twig girdlers reduce leaf area due to their girdling behavior (CORDEIRO et al., 2006; LEMES et al., 2013; PEDROZO, 1980) and in this work it was found that there was reduction in the development of "girdled" A. mangium trees similar to those with defoliated central leader.

\section{CONCLUSION}

The cut of the central leader, in a similar way to that made by $O$. saga, reduced height growth. The height growth of trees that had the central leader "girdled" had an similar reduction in growth as those that were defoliated.

\section{ACKNOWLEDGMENTS}

To the Coordenação de Aperfeiçoamento de Pessoal de Nível Superior (CAPES) for financial support.

\section{REFERENCES}

ABBOTT, I.; HEURCK, P.V.; BURBIDGE, T. Impact of frequency and intensity of defoliation on growth of Jarrah (Eucalyptus marginata), an experimental study with saplings. Forest Ecology and Management, v. 56, p. $175-183,1993$.

AGEFLOR - ASSOCIAÇÃO GAÚCHA DE EMPRESAS FLORESTAIS. A indústria de base florestal no Rio Grande do Sul 2017. Porto Alegre, 2017. 60 p. Disponível em: < http://www.ageflor.com.br/noticias/wpcontent/uploads/2017/08/A-INDUSTRIA-DE-BASE-FLORESTAL-NO-RS-2017.pdf >. Acesso em: 30 jan. 2018.

ARCO-VERDE, M. F. Potencialidades e usos da Acacia mangium Willd. no estado de Roraima. Boa Vista: Embrapa Roraima, 2002. 18 p. (Embrapa Roraima. Documentos, 6).

CARAGLIO, Y.; NICOLINI, E.; PETRONELLI, P. Observations on the links between the architecture of a tree (Dicorynia guianensis Amshoff) and Cerambycidae activity in French Guiana. Journal of Tropical Ecology, v. 17, p. 459-463, 2001. 
Cordeiro et al. - Simulation of Oncideres saga (Dalman) girdling over Acacia

mangium Willd. development

CEUlEmAnS, R. J.; SAUGIER, B. Photosynthesis. In: Raghavendra, A. S. Physiology of Trees. Hyderabad: John Wiley \& Sons, 1991. p.21-50.

CANTARELLI, E. B.; COSTA, E. C.; PEZZUTTI, R.; OLIVEIRA, L. S. Quantificação das perdas no desenvolvimento de Pinus taeda após o ataque de formigas cortadeiras. Ciência Florestal, v. 18, n. 1, p. 39-45, 2008.

CORDEIRO, G. Aspectos biológicos de Oncideres saga (Dalman) (Coleoptera: Cerambycidae) e efeitos de seus danos em Acacia mangium Willd. 2008. 82 p. Dissertação (Mestrado em Entomologia) - Universidade Federal de Viçosa, Viçosa, 2008.

CORDEIRO, G.; ANJOS, N.; LEMES, P. G.; MATRANGOLO, C. A. R. Ocorrência de Oncideres dejeanii Thomson (Cerambycidae) em Pyrus pyrifolia (Rosaceae), em Minas Gerais. Pesquisa Florestal Brasileira, v. 30, n. 62, p. 153-156. 2010.

CORDEIRO, G.; ANJOS, N.; FERNANDES, L. C.; PEREIRA, L. P. Potencial de injúrias de Oncideres saga (Dalman, 1823) (Coleoptera: Cerambycidae) em Acacia mangium. In: CONGRESSO BRASILEIRO DE ENTOMOLOGIA, 21, 2006, Recife, Anais... Recife: SBE, 2006.

COULSON, R. N. Population dynamics of bark beetles. Annual Review of Entomology, v. 24, p. 417-447, 1979.

CORASSA, J. D. N.; SOUZA, R. M. Besouros desfolhadores em plantações florestais. In: CANTARELLI, E. B.; COSTA, E. C. (Org.). Entomologia Florestal Aplicada. Santa Maria: Editora UFSM, 2014, p. 123-144.

COUTINHO, C. L.; CARVAlHO, A. C.; OliveIRA, E. S.; VEIGA, B. G. A. Oncideres saga (Dalman, 1823) (Coleoptera: Cerambycidae) e a arborização urbana em Seropédica, RJ. Floresta e Ambiente, Rio de Janeiro, v. 5 , n. 1 , p. $50-54,1998$.

CUNIA, T. Dummy variables and some of their uses in regression analysis. In: CUNIA, T.; KUUSELA, K.; NASH, A.J. Proceedings of the June 1973 meeting ofInternational Union of Forestry Research Organizations meeting subject groupS4.02, Nancy, France. Syracuse, NY: College of Environmental Sciences and Forestry, State University of New York, 1973.146 p. v. 1.

DE NADAI, J.; ANJOS, N.; LEITE, H. G. Ataque de Lampetis nigerrima (Kerremans, 1897) (Coleoptera: Buprestidae) e poda de formação em clone de eucalipto. Ciência Florestal, Santa Maria, v. 22, n. 3, p. 519-531, 2012.

DI IORIO, O. R. Cerambycidae y otros Coleoptera emergidos de ramas cortadas por Oncideres germari (Lamiinae: Onciderini) en el Norte Argentino. Revista de Biologia Tropical. v. 42, n. 3, p. 649-661, 1996.

DICKSON, R. E. Assimilate distribution and storage. In: RAGHAVENDRA, A. S. Physiology of Trees, Hyderabad: John Wiley \& Sons, p. 51-85, 1991.

FERNANDES, L. C. Biologia de Metaxyonycha angusta (Perty) (Coleoptera: Chrysomelidae) e efeitos do seu ataque em eucaliptos, num sistema agroflorestal. 2004. 86 p. Dissertação (Mestrado em Entomologia) - Universidade Federal de Viçosa, Viçosa, 2004.

FREITAS, S.; BERTI FILHO, E. Efeito do desfolhamento parcial e total na produção de biomassa de Eucalyptus grandis em Mogi Guaçu, São Paulo. IPEF, n. 47, p. 29-35, 1994 a.

FREITAS, S.; BERTI FILHO, E. Efeito do desfolhamento no crescimento de Eucalyptus grandis Hill Ex. Maiden (Myrtaceae). IPEF, n. 47, p. 36-43, 1994b.

FREITAS, S.; MACHADO, C. F. Efeito do desfolhamento no crescimento de árvores de Eucalyptus grandis Hill ex Maiden com nove meses de idade. Científica, v. 26, n. 1/2, p. 73-81, 1998.

GALILEO, M. H. M.; MARTINS, U. R. Cerambycidae (Coleoptera) Parque Copesul de Proteção Ambiental, Triunfo, Rio Grande do Sul. Porto Alegre: Museu de Ciências Naturais da Fundação Zoobotânica do Rio Grande do Sul, 2006. 314 p.

IBÁ - INDUSTRIA BRASILEIRA DE ÁRVORES. Relatório Ibá 2017. Brasília, 2017. 77 p. Disponível em: < http:// iba.org/images/shared/Biblioteca/IBA_RelatorioAnual2017.pdf >. Acesso em: 30 jan. 2018.

LEMES, P. G.; CORDEIRO, G.; JORGE, I. R.; ANJOS, N. D.; ZANUNCIO, J. C. Cerambycidae and other Coleoptera associated with branches girdled by Oncideres saga Dalman (Coleoptera: Cerambycidae: Lamiinae: Onciderini). The Coleopterists Bulletin, v. 69, n. 1, p. 159-166, 2015. 
LEMES, P. G.; ANJOS, N.; JORGE, I. R. Bioecology of Oncideres ocularis Thomson (Coleoptera: Cerambycidae) on Acacia mangium Willd. (Fabaceae), Journal of the Kansas Entomological Society, v. 86, n. 4, p. 307-317, 2013.

LEMES, P. G.; AFONSO, R.; ANJOS, N. D.; SARMENTO, R. A.; LEITE, P. J. B.; CORONETTI, J. A. First host record of Oncideres mirim Martins and Galileo, 1996 (Coleoptera: Cerambycidae) on Acacia mangium Willd.(Fabaceae). The Coleopterists Bulletin, v. 66, n. 2, p. 173-176, 2012.

MAFIA, R. G.; MENDES, J. E. P.I; CORASSA, J. N. Análise comparativa dos surtos e danos causados pelos besouros desfolhadores Costalimaita ferruginea (Fabricius, 1801) e Costalimaita lurida (Lefévre, 1891) (Coleoptera: Chrysomelidae) em plantios de eucalipto. Revista Árvore, v. 38, n. 5, p. 829-836, 2014.

MATRANGOLO, C. A. R.; CASTRO, R. V. O.; DELlA LUCIA, T. M. C.; DELLA LUCIA, R. M.; MENDES, A. F. N.; COSTA, J. M. F. N.; LEITE, H. G. Crescimento de eucalipto sob efeito de desfolhamento artificial. Pesquisa Agropecuária Brasileira, v. 45, n. 9, p. 952-957, 2014.

MENDES, J. E. P. Efeitos do ataque de Costalimaita ferruginea (Fabr.) (Coleoptera: Chrysomelidae) sobre crescimento e produção de Eucalyptus grandis Hill ex Maiden. 2004. 49 p. Tese (Doutorado em Entomologia) - Universidade Federal de Viçosa, Viçosa, 2004.

MENDES, J. E. P. Nível de dano e impacto do desfolhamento por Costalimaita ferruginea (Fabr.) (Coleoptera: Chrysomelidae) em Eucalyptus grandis Hill ex Maiden. 1999. 99 p. Dissertação (Mestrado em Entomologia) - Universidade Federal de Viçosa, Viçosa, 1999.

OHMART, C.P.; THOMAS, J.; STEWART, L.G. Differential defoliation by insects among provenances of Eucalyptus delegatensis. Journal of Australian Entomological Society, v. 23, p.105-111, 1984.

OlIVEIRA, M. A.; LUCIA, T. M. C. D.; DELlA LUCIA, R. M. D.; ANJOS, N.; ARAUJO, M. S.; LEITE, B. S. . The simulated effect of defolation in the growth of the Eucalyptusgrandis. Chemical Engineering Transactions, v. 39, p. 1543-1548, 2014.

OLIVEIRA, L. S. Aspectos entomológicos em povoamentos homogêneos de Acacia mearnsii De Willd. 2007. 121 p. Tese (Doutorado em Engenharia Florestal) - Universidade Federal de Santa Maria, Santa Maria, 2007.

PEDROZO, D. J. Contribuição ao estudo de Oncideres impluviata (Germar, 1824) e seus danos na bracatinga (Minosa scabrella Benth.). 1980. 83 p. Dissertação (Mestrado em Engenharia Florestal) Universidade Federal do Paraná, Paraná, 1980.

REIS FILHO, W.; SANTOS, F.; STRAPASSON, P.; NICKELE, M. A. Danos causados por diferentes níveis de desfolha artificial para simulação do ataque de formigas cortadeiras em Pinus taeda e Eucalyptus grandis. Pesquisa Florestal Brasileira, v. 31, n. 65, p. 37, 2011.

ROMERO, G. Q.; VASCONCELLOS-NETO, J.; PAULINO NETO, H. F. The effects of the wood-boring Oncideres humeralis (Coleoptera, Cerambycidae) on the number and size structure of its host-plants in south-east Brazil. Journal of Tropical Ecology, Cambridge, v. 21, p. 233-236, 2005.

SCHOWALTER, T. D.; HARGOVE, W. W.; CROSSLEY JUNIOR, D.A. Herbivory in forested ecosystems. Annual Review of Entomology, v. 31, p.177-196, 1986.

SILVA, E. J. Identificação de formigas cortadeiras e efeito do desfolhamento simulado em plantios de seringueira (Hevea brasiliensis Mull Arg.). 2001. 37 p. Dissertação (Mestrado em Entomologia) - Universidade Federal de Viçosa, Viçosa, 2001.

SOUZA, G. K.; PIKART, T. G.; PIKART, F. C.; ZANUNCIO, J. C. Registro de Oncideres saga (Coleoptera: Cerambycidae) em Peltophorum dubium (Leguminosae) no Município de Trombudo Central, Santa Catarina, Brasil. EntomoBrasilis, v. 5, n. 1, p. 75-77, 2012.

STATSOFT INCORPORATION. STATISTIC (data analysis software system), version 8.0, 2012.

VIDAURRE, G. B.; JORGE, A. C.; CÔRTES, M. S.; CARVALHO, A. G. Preferência de incisão de postura por Oncideres saga (Dalman) (Coleoptera: Cerambycidae) por terço em ramo de Acacia mangium Willd. In: SIMPÓSIO DE BIOLOGIA DA UNISANTA, 6, 2001a, Santos. Anais... Santos: UNISANTA, 2001. 62 p. 
WENDT, J. G. N.; SILVA, E. M. R.; CARVALHO, A. G. Ocorrência e avaliação de danos de Oncideres saga (Dalman, 1823) (Coleoptera: Cerambycidae) em Acacia mangium Willd. In: CONGRESSO BRASILEIRO DE ENTOMOLOGIA, 13, 1998, Rio de Janeiro. Resumos... Rio de Janeiro: SBE, 1998. 759 p.

WYLIE, F. R.; SPEIGHT, M. R. Tropical forest pests: ecology, biology and impact. In: Insect Pests in

Tropical Forestry. Wallingford: CABI, 2012. p. 91-152.

Received: 2018/06/03

Accepted: 2019/28/01 